Supplement of Nat. Hazards Earth Syst. Sci., 20, 1069-1096, 2020

https://doi.org/10.5194/nhess-20-1069-2020-supplement

(C) Author(s) 2020. This work is distributed under

the Creative Commons Attribution 4.0 License.

(c) (1)

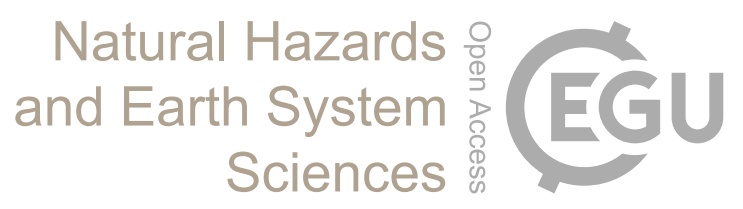

Supplement of

\title{
Review article: Natural hazard risk assessments at the global scale
}

Philip J. Ward et al.

Correspondence to: Philip J. Ward (philip.ward@vu.nl)

The copyright of individual parts of the supplement might differ from the CC BY 4.0 License. 


\section{River floods}

25 Studies of current flood risk, without future projections

Dilley et al. (2005) mapped the proportion of national population in areas highly exposed to river floods. Flooding was represented by areas listed as having faced extreme floods between 1985-2003 in the World Atlas of Large Flood Events of the Dartmouth Flood Observatory. The same flood dataset was used by Güneralp et al. (2015) to map potential changes in urban areas in flood-prone regions. As the report of Dilley et al. (2005) states, this gives a general impression of regions

30 affected by floods, but not necessarily actual inundated areas. For this reason, these studies are not included in Table 1.

The Global Assessment Report (GAR) 2015 (UNDRR, 2015a) contains estimates of current flood risk at the global scale using the global flood model developed by Rudari et al. (2015). Risk is expressed in terms of direct damage. Hazard is represented by maps of inundation extent and depth $(1 \mathrm{~km} \times 1 \mathrm{~km})$ derived from a 1D hydraulic model that draws hydraulic cross-sections from a global Digital Elevation Model (DEM) with a horizontal resolution of $90 \mathrm{~m} \times 90 \mathrm{~m}$. The hydraulic model is forced by

35 estimates of extreme discharge for return periods of 25, 50, 100, 200, 500, and 1000 years. Exposure is represented using a common dataset used throughout GAR2015, which includes exposed assets and population at a horizontal resolution of $5 \mathrm{~km}$ x $5 \mathrm{~km}(1 \mathrm{~km} \times 1 \mathrm{~km}$ along the coastline only) (De Bono and Chatenoux, 2015). Vulnerability is represented by depth-damage functions designed for the GAR2015 (UNDRR, 2015). The calculations are carried out at a resolution of 30" x 30", and then integrated across exceedance probabilities to calculate probabilistic risk (protection standards are not accounted for). The study

40 only examines current risk, so no projections or future DRR measures are included.

Ward et al. (2013) published the first global application of the GLOFRIS global flood risk assessment framework. Risk indicators used are affected population, GDP, and agricultural value, as well as urban damage to buildings. In this study, only current risk is examined. The framework was subsequently applied to examine future risk in several papers, as discussed later. Hazard is represented by maps of inundation extent and depth for several return periods at 30" x 30". These are modelled using

45 the the PCR-GLOBWB-DynRout model (Van Beek et al., 2011) coupled with a volume spreading inundation algorithm (Winsemius et al., 2013). For current climate, the model is forced with daily climate data from the EU-WATCH project (Weedon et al 2011). Current exposure is represented by: population and GDP at 30" x 30" from Van Vuuren et al. (2007); land use from the HYDE database (Klein Goldewijk et al., 2010) (resampled from 5' x 5' to 30" x 30"); and agricultural values per cell (30" x 30"), calculated using an adapted version of Dilley et al. (2005). Vulnerability is represented by a depth-damage

50 function showing the average of high and low urban density land class functions in the Damagescanner model (Klijn et al., 2007). The calculations are carried out at a resolution of 30" x 30"; and then integrated across exceedance probabilities to calculate probabilistic risk (protection standards are not accounted for). The study only examines current risk, so no projections or future DRR measures are included.

Projections of change in people affected by change in extreme discharge

55 The earliest projections of global scale river flood risk use various indicators of extreme discharge at a coarse spatial scale $\left(0.5^{\circ} \times 0.5^{\circ}\right.$ to 'large river basins') as a proxy for hazard, and population data at the same scale as a proxy for exposure (Kleinen 
and Petschel-Held, 2007; Hirabayashi and Kanae, 2009; Arnell and Lloyd-Hughes, 2014; Arnell and Gosling, 2016). Both hazard and exposure use dynamic projections, and vulnerability and future DRR measures are not included. Risk is expressed in terms of affected population, either per year or for individual return periods. None of these studies assess probabilistic risk,

60 include current protection standards, or include future DRR measures. The first of these studies, by Kleinen and Petschel-Held (2007), uses a simple approach to assess the fraction of world population living in river basins affected by changes in 'flood probability' between the 20th century and 2100 , whereby flood probability is the probability of monthly basin-scale discharge exceeding different return levels. Risk is the number of people living in each basin for different return periods of monthly discharge. Hazard is represented as the monthly discharge for different return periods (2 to 50 years) at river basin scale. A 65 simple monthly rainfall-runoff model is forced with monthly climate data from the CRU-PIK dataset $\left(0.5^{\circ} \times 0.5^{\circ}\right)$ (Österle et al., 2003) for current climate, and patterns of temperature and precipitation change from three GCMs scaled to the current climate dataset for future climate. Exposure is represented by the population of each large basin aggregated from the Gridded Population of the World v2 (GPWv2) dataset of CIESIN (2000). For each basin, future population is estimated by interpolating the median population projections of IIASA (Lutz et al. 2004). The main finding is that up to $20 \%$ of the world's population 70 is likely to be affected by increased flood events by 2080 .

Hirabayashi and Kanae (2009) note two major limitations in the study of Kleinen and Petschel-Held (2007): (a) the use of monthly surface runoff and lack of discharge routing; and (b) the use of basin scale for the analysis. Therefore, they use modelled routed daily discharge to assess risk in terms of the population per cell affected by discharge exceeding current 50 and 100 year return levels. The calculations are carried out at $1.0^{\circ} \times 1.0^{\circ}$. For each year, the number of affected people is 75 calculated by summing the population in cells where the maximum discharge of that year exceeds the current 50 or 100 year return levels. Current hazard is represented by gridded maps of 50 and 100 year return period discharge $\left(1.0^{\circ} \times 1.0^{\circ}\right)$. These are simulated using the MATSIRO land surface model (Hirabayashi et al., 2005), forced by daily runoff from the MATSIRO GCM for 1901-2000. Future hazard is represented by gridded maximum discharge per year $\left(1.0^{\circ} \times 1.0^{\circ}\right)$, derived from the same model setup forced by future GCM data for 2000-2100 under the SRES A1B scenario (Nakicenovic et al., 2000).

80 Exposure is represented by gridded decadal population data $\left(1.0^{\circ} \times 1.0^{\circ}\right)$ until 2100 . The main findings are that currently 20 to 300 million people per year are affected by floods, and that in the case of $3^{\circ} \mathrm{C}$ warming, approximately 300 million people could be affected even in years of relatively low flooding.

Arnell and Lloyd-Hughes (2014) assess the number of people living in areas where the frequency of the current (1961-1990) 20-year discharge either doubles or halves by 2050 and 2080. Arnell and Gosling (2016) published a similar study (using

85 different input data to generate hazard) in which they also assess changes in cropland area. In both papers, calculations are carried out at $0.5^{\circ} \times 0.5^{\circ}$. Hazard is represented by maps of 20 year return period discharge $\left(0.5^{\circ} \times 0.5^{\circ}\right)$, generated using the MacPDM.09 model (Gosling and Arnell 2011). For current climate, the model is forced by daily climate data from the CRU TS3.10 dataset (Harris et al. 2013). For future climate, it is forced by: bias-corrected daily climate data from 19 GCMs from the Climate Model Intercomparison Project 5 (CMIP5) (Taylor et al. 2012) for four Representative Concentration Pathways 90 (RCPs) in Arnell and Lloyd-Hughes (2014); and by pattern-scaling output from 21 GCMs from CMIP3 for SRES scenarios 
(Meehl et al. 2007) in Arnell and Gosling (2016). Exposure is represented by gridded population data $\left(0.5^{\circ}\right.$ x $\left.0.5^{\circ}\right)$ taken from the IMAGE 2.3 model (Van Vuuren et al., 2007); in Arnell and Lloyd-Hughes (2014) future data are from the five Shared Socioeconomic Pathways (SSPs), whilst in Arnell and Gosling (2016) they are taken from the SRES storylines. Both studies project a large number of people exposed to a doubling in flood hazard by 2050: 235-381 million depending on SSP/RCP

95 combination (averaged across GCMs) in Arnell and Lloyd-Hughes (2014), and 323-570 million depending on SRES scenario combination in Arnell and Gosling (2016).

\section{Initial projections based on inundation mapping}

Jongman et al. (2012) is the first study to project changes in risk using inundation maps. They assess population, assets, and area exposed to a 100 year return period flood, as well as maximum potential direct damage from a 100 year return period

100 flood. The projections are carried out assuming constant hazard, but dynamic projections of exposure until 2050. As before, vulnerability and future DRR measures are not accounted for, and probabilistic risk is not assessed. The calculations are carried out at a resolution of 30" x 30 ". Hazard is represented using the 100 year return period flood extent map of Herold and Mouton (2011), developed for the GAR2009 (UNDRR, 2009) by combining hydrological modelling and historic flood records. Current exposure is represented by population density and land use maps for 2005 from the HYDE database (Klein Goldewijk et al.,

105 2010), resampled from 5' x 5' to 30" x 30". Future population maps are developed by multiplying the current population maps with changes per country from the World Bank's population projections of Hughes et al. (2010). Future land use is extrapolated from 2005 onwards using the same population projections and projections of changes in relative urbanisationThe main findings are increases by 2050 of: global population exposed (31\%); exposed assets (250\%); urban area exposed (61\%); and maximum damage (200\%).

110 Hirabayashi et al. (2013) use dynamic hazard projections, but static exposure, to assess the number of people exposed to 10 and 100 year return period floods for each year from 1970-2100. Neither vulnerability nor future DRR measures are accounted for. The calculations are carried out at a resolution of $2.5^{\prime} \times 2.5^{\prime}$. Hazard is represented by maps of inundation extent $\left(2.5^{\prime} \mathrm{x}\right.$ $2.5^{\prime}$ ), derived by downscaling water levels at $0.25^{\circ} \times 0.25^{\circ}$ from the CaMa-Flood hydrodynamic model (Yamazaki et al., 2011) onto a high-resolution DEM. CaMa-Flood is forced directly with runoff from 11 GCMs from CMIP5 (Taylor et al., 2012) for

115 RCPs 2.6, 4.5, 6.0, and 8.5. Exposure is represented using the GPWv3 population dataset (CIESIN, 2005), resampled to 2.5' x 2.5'. The main findings are a global increase in the number of exposed people by factors ranging from 4-14 by 2100, with especially large increases in Southeast Asia, Peninsular India, eastern Africa, and the northern half of the Andes.

Probabilistic risk assessments of future risk

None of the aforementioned studies of future flood risk assess probabilistic risk. All of the remaining studies in this subsection

120 use a probabilistic approach in which impacts are calculated for a range of return periods, and then integrated across exceedance probabilities to estimate expected annual impacts. This approach is also used in the aforementioned assessments of current risk by Ward et al. (2013) and UNDRR (2015a). In doing so, the majority of the studies below also attempt to account for the fact that many regions of the world are already protected against flooding by structural measures. To do this, the exceedance probability-impact curve (risk curve) is truncated for return periods lower than an assumed protection standard. These studies 
have either assumed uniform protection standards globally or across different income groups, or used modelled protection standards per state from the FLOPROS database (Scussolini et al., 2016).

Alfieri et al. (2017) simulate changes in risk due to climate change only, under three warming scenarios corresponding to $1.5^{\circ} \mathrm{C}, 2^{\circ} \mathrm{C}$, and $4^{\circ} \mathrm{C}$ compared to pre-industrial levels. Exposure and vulnerability are static, and future DRR measures are not accounted for. Risk indicators used are affected population and direct damage. The calculations are carried out at a resolution

130 of 30 " x 30 ", and integrated across exceedance probabilities to calculate probabilistic risk using protection standards from FLOPROS. Hazard is represented by maps of inundation extent and depth for several return periods at 30" x 30", modelled using a global version of Lisflood described in Dottori et al. (2016). For current climate, Lisflood is forced with daily climate data from the ERA-Interim reanalysis dataset, with precipitation bias-corrected with the Global Precipitation Climatology Project (GPCP) v2.1 dataset (Huffman et al., 2009). For future climate, Lisflood is forced with seven GCMs downscaled using 135 the EC-EARTH3-HR v3.1 model (Hazeleger et al., 2012) to a resolution of $0.35^{\circ} \times 0.35^{\circ}$. Time slices of 30 -years are chosen from RCP8.5 simulations to represent global warming of $1.5^{\circ} \mathrm{C}, 2^{\circ} \mathrm{C}$, and $4{ }^{\circ} \mathrm{C}$. For exposure, population data are taken from the Global Human Settlement Layer Global Population Grids (Pesaresi et al., 2013; Freire et al., 2015), and land use data are taken from the GlobCover 2009 (Bontemps et al., 2011); both are upscaled to 30" x 30". Vulnerability is represented by sector and country specific depth-damage functions from Huizinga and De Moel (2016). The main findings are a more than four-fold

140 increase in global risk by 2100 due to climate change alone under the $4^{\circ} \mathrm{C}$ warming scenario, with countries representing $>70 \%$ of the global population and GDP projected to face significant increases in flood risk exceeding $500 \%$.

Dottori et al. (2018) carried out a similar study to Alfieri et al. (2017), but with several differences: (a) they also examine fatalities and indirect damage; they use warming scenarios corresponding to $1.5^{\circ} \mathrm{C}, 2^{\circ} \mathrm{C}$, and $3^{\circ} \mathrm{C}$; they include dynamic exposure projections; and they use a different hazard modelling framework. Vulnerability is static, and future DRR measures

145 are not accounted for. The calculations are carried out at a resolution of $2.5^{\prime} \times 2.5^{\prime}$, and integrated across exceedance probabilities to calculate probabilistic risk using protection standards from FLOPROS. Hazard is calculated using the same CaMa-flood setup as Hirabayashi et al. (2013), but forced with runoff fields from 10 global hydrological models (GHMs). The GHMs are forced with bias-corrected climate data from CMIP5 (Taylor et al., 2012), using RCP8.5. Current exposure is represented using the same population and land use data as Alfieri et al., (2017). Future population data are taken from Van 150 Vuuren et al. (2017), regridded from original resolution $\left(7.5^{\prime} \times 7.5^{\prime}\right)$ to $2.5^{\prime} \times 2.5^{\prime}$. Future spatial exposure of assets is developed by scaling the current land-use maps using macro-regional projections of urban and cropland change of Van Vuuren et al. (2017) for SSP3 and SSP5. For direct damage, the same depth-damage functions are used to represent vulnerability as in Alfieri et al. (2017). Mortality is represented using the ratio of reported fatalities to modelled affected people (mortality ratio), following Jongman et al. (2015) - see below for details. Indirect economic impacts are simulated using the macro-econometric 155 of the global economy (MaGE) model (Fouré et al., 2013). The main findings are global increases in fatalities of 70-83\%, 103$134 \%$, and $180 \%-265 \%$, for $1.5,2$ and $3{ }^{\circ} \mathrm{C}$ global warming, respectively, depending on SSP. Global increases in expected annual damage are higher, at 160-240\%, 320-520\%, and 620-1,000\% billion per year respectively, depending on SSP. 
Winsemius et al. (2016) and Ward et al. (2017) project future urban damage in 2030 and 2080 using dynamic hazard and exposure, and static vulnerability. Both studies make use of the GLOFRIS framework of Ward et al. (2013). The calculations

160 are carried out at a resolution of 30" x 30", integrated across exceedance probabilities to probabilistic risk. In Winsemius et al. (2016), current risk is estimated under two assumptions: (a) no flood protection; and (b) flood protection corresponding to a 100 year return period in high income countries and a 5 year return period in other income regions. This is the first global river flood risk study to include future DRR measures; in calculating future risk it is assumed that dikes and levees would be upgraded in the future to maintain their current flood protection standard. Ward et al. (2017) extend the assessment of future

165 DRR measures, by developing a module to explicitly assess the costs and benefits of namely dikes and levees. They use the FLOPROS database to estimate current risk per state, and then explore three 'adaptation objectives'. In these studies, hazard is represented by maps of inundation extent and depth for several return periods at 30" x 30". These are modelled using the the PCR-GLOBWB-DynRout model (Van Beek et al., 2011) coupled with a volume spreading inundation algorithm (Winsemius et al., 2013). For current climate, the model is forced with daily climate data from EU-WATCH (Weedon et al

170 2011). For future climate, it is forced with bias-corrected daily climate data from five GCMs from the ISI-MIP project (Hempel et al., 2013) for RCPs 2.6, 4.5, 6.0, and 8.5. Exposure is represented using the same data as Jongman et al. (2012) at 30" x 30", but for SSP1-5. Vulnerability is represented by a depth-damage function showing the average of high and low urban density land use functions in the Damagescanner model (Klijn et al., 2007). The main findings of Winsemius et al. (2016) are an average increase in global risk across GCMs by 2080, with the simple assumption of flood protection, by $1400 \%, 500 \%$, and

$1752600 \%$ respectively. Relative to GDP, these translate to increases in risk of 92\%, 28\%, and 128\%. Ward et al. (2017) show that future risk (in 2080) can be kept constant to current levels (both in terms of absolute values and relative to GDP) though future DRR measures, and map those regions where this could be achieved through structural measures with benefits outweighing costs. Robust areas are found across most of North America, northwestern and central Europe, the Indian Subcontinent, large parts of East and Southeast Asia, and large parts of Australasia. Next to these regions, they show that the

180 benefits of structural measures also outweigh the costs in the Indian Subcontinent, parts of Central Africa, and along the Nile Valley, although in those regions future risk would still increase compared to today.

Willner et al. (2018) also assess protection standards that would be required to keep future risk in 2040 constant compared to the current level, but focusing on the number of affected people. This study only uses dynamic projections of hazard. Exposure is static and vulnerability is not accounted for. The calculations are carried out at a resolution of $0.25^{\circ} \times 0.25^{\circ}$, and integrated

185 across exceedance probabilities to calculate probabilistic risk using protection standards from FLOPROS. Hazard is represented by maps of inundated fraction at 2.5' x 2.5', calculated using Cama-Flood (Yamazaki et al., 2011). Daily runoff data from 10 Global Hydrological Models (GHMs) are used as input to Cama-Flood, with each hydrological model being forced with EU-WATCH data for the current period, and bias-corrected climate data for 2035-2044 from 5 GCMs from the ISI-MIP project (Hempel et al., 2013) using RCPs 2.6, 4.5, 6.0, and 8.5. Exposure is represented by gridded population (2.5' 190 x 2.5') for 2010 from the GRUMP database (CIESIN, 2016). The main findings are that strongest future DRR efforts are 
required for most of the United States, Central Europe, and Northeast and West Africa, as well as large parts of India and Indonesia.

Jongman et al. (2015) is the first global flood risk study to use dynamic projections of hazard, exposure, and vulnerability, and examines changes in expected annual fatalities and (direct) losses between 2010, 2030, and 2080. The calculations are carried

195 out at a resolution of 30 " x 30", and aggregated to expected annual values at global scale by integrating impacts across all exceedance probabilities. Hazard and exposure are represented using the same data as Winsemius et al. (2016) and Ward et al. (2017). Vulnerability is represented using mortality and loss ratios. First, these are calculated for each country and year, deriving a ratio of: (a) reported fatalities to modelled affected people (mortality ratio); and (b) reported losses to modelled affected GDP (loss ratio). These ratios are then averaged across World Bank income groups for 1980-2010. Dynamic

200 vulnerability is incorporated by developing three vulnerability scenarios: 'no additional adaptation' scenario, in which static vulnerability ratios are used; (b) 'medium adaptation' scenario, in which all countries converge to the current average global vulnerability ratios by 2080; and (c) 'high adaptation' scenario, in which all countries converge to the current vulnerability ratios in high-income countries by 2080. For the future time-periods, 300 model simulations were carried out, for a combination of 5 GCMs, 4 RCPs, 5 SSPs, and 3 vulnerability scenarios. The main finding is that future increase in flood risk can largely

205 be contained through vulnerability reduction (note that in this study this includes any measures to reduce flood risk).

\section{Coastal floods}

Early simulations of coastal flood risk and adaptation for the IPCC

Hoozemans (1993) is the first to conduct a global scale assessment of coastal flood hazard and risk, responding to needs put forward by the Coastal Zone Management Subgroup (CZMS) of the International Panel on Climate Change (IPCC). This study

210 is the first of its kind to cover both risks of long-term gradual sea level rise as well as extreme events. Risk indicators used include permanent loss of capital, wetlands, rice cultivation areas, and land in general. Extreme sea levels are estimated using empirical approaches relating coastal bathymetry and wind and pressure extremes (derived from wave climate estimates) to expected tide and surge extremes. Combined with coastal elevation zones, these are used to estimate hazard, expressed as the potential inundated land for different probabilities (1, 10, 100, 1000-year return periods). Exposure is represented by estimates

215 of regional population (taken from general sources such as encyclopaedias at provincial level), capital, presence of wetlands, and cultivation areas to assess risk. Vulnerability is not included. The calculations are carried out at a country resolution, and integrated across exceedance probabilities to calculate probabilistic risk. In this calculation, a conservative estimate of current protection is included in the form of a design frequency in three return period classes (1-10 years, 10-100 years, 100-1000 years), distributed along the coastline based on the income per capita). Hoozemans (1993) also carried out a first-cut analysis

220 of changes in these risk estimates as a consequence of trends in population based on World Bank and UN numbers, an assumed uniform $1 \mathrm{~m}$ sea level rise, and a conservative estimate of subsidence of $1.5 \mathrm{~mm}$ per year within delta areas only. Future DRR measures and their costs are calculated by estimating construction costs to raise each coastline's protection standard from one 
safety category to the next. The main results are that annual average affected people was in the order of 50 million people in 1990, and that this could increase by $50 \%$ by 2020 without future DRR measures, and by $100 \%$ including population growth.

Total costs of future DRR measures are estimated to be US $\$ 500$ billion, resulting in a decreased risk to over 50 million people per year.

\section{The development and early uses of the DIVA model}

Hinkel and Klein (2009) recognised a number of shortcomings in the study of Hoozemans (1993), including: low resolution input data; limited set of scenarios; no dynamic feedbacks between biophysics and socio-economics; and a simplistic representation of future DRR measures. To address these issues, the Dynamic Interactive Vulnerability Assessment Tool (DIVA) tool (described extensively by Vafeidis et al. (2008)) was developed. The tool assesses coastal risk and future DRR measures dynamically (5-year time steps) along the global coastline, considering 12,148 coastal segments. These coastal segments are selected and disaggregated from the global coastline on the basis of similarity and where socio-economic activities are concentrated, and therefore have a varying length. In DIVA, population, GDP, and other properties are aggregated

235 to coastline segments, in elevation zones with $1 \mathrm{~m}$ increments, using various gridded population maps as inputs. Several future DRR measures can be considered in DIVA, including dike building, beach nourishment, tidal nourishment, and wetland nourishment.

Hinkel et al. (2010) use DIVA to model risk for indicators including direct damage, affected people, and affected GDP per DIVA segment. Vulnerability is represented by one depth-damage function for calculating direct damage. Integration from

240 impacts to risk is done by integrating the 1,10,100, and 1000-year return period impact estimates. Current (1995) protection standards are estimated using the "demand for safety" approach, essentially relating the amount of expected damage without protection to the actual protection standard. This approach is more elaborately described in Hinkel et al. (2014, see below). For future scenarios, pairs of sea-level rise and socio-economic scenarios are taken from the SRES scenarios. Subsidence is conservatively estimated with a rate of $2 \mathrm{~mm}$ per year. Future DRR measures are assessed using two strategies: one in which

245 future risk is kept constant at current levels, and one based on balancing benefits and costs. The main findings are that by 2100 , up to 200 million people could be annually affected by floods.

Hallegatte et al. (2013) use DIVA to assess expected annual damage in 2050 in major coastal cities. Impacts are integrated across exceedance probabilities to calculate probabilistic risk using an empirical database of actual protection standards (based on expert judgement) within the 136 largest coastal cities. Future DRR measures, and their costs, are included by focusing on

250 structural measures using the approach of Hallegatte et al. (2011). Future hazard is represented by adding conservative sea level rise numbers of 20 to $40 \mathrm{~cm}$ to current sea level, and subsidence by either adding zero (no subsidence) or $40 \mathrm{~cm}$. Future exposure scenarios are taken from Chateau et al. (2011). The main findings are that in these cities current expected annual damage is about US\$6 billion per year. Without future DRR measures, this could increase to US\$52 billion per year under a socio-economic growth only scenario and to US $\$ 1$ trillion per year when sea level rise and subsidence are considered. They find that risk can be contained at current levels by implementing future DRR measures that reduce flood probabilities to below current levels, with the benefits of such a strategy far outweighing the costs. 
Hinkel et al. (2014) perform an integrated coastal risk assessment, based on DIVA. They use a wide variety of consistent socioeconomic and sea-level rise scenarios (Hinkel et al. 2014). Integration to risk, as well as current protection estimation, are done with the same methods as used by Hinkel et al. (2010). Future DRR measures, and their costs, are assessed in terms of allowing

260 dike heightening through time as the demand for safety increases due to sea level rise and socio-economic development. This is the first study to include spatially explicit sea level rise scenarios, using three RCPs. The main result is that by 2100, 0.2$4.6 \%$ of the global population will be flooded annually without additional DRR measures, and that expected annual damage will be $0.3-9.3 \%$ of global GDP. They show that the costs of future DRR measures are considerable, but are dwarfed by the benefits in terms of decreased risk.

265 Jongman et al. (2012) apply the same methodology as the one they use for river flooding to assess future scenarios of coastal flood risk due to changes in exposure only. They assess population, assets, and area exposed to a 100 year return period flood, as well as maximum potential direct damage from a 100 year return period flood, all at 30" x 30 ". Unlike the previous studies using DIVA, they use gridded inundation maps to represent the hazard, rather than inundation zones over fixed coastline segments of coastal hazard. A hazard map (30" x 30") for a 100 year return period flood is developed by taking the 100-year return period sea water levels from the DIVA database (Vafeidis et al., 2008), and defining hazard areas as those cells below this water level with the direct connection to the coast using the SRTM DEM (Jarvis et al., 2008). Exposure is assessed for current and future conditions using the same data as previously described for river flooding. Future DRR measures are not accounted for, and probabilistic risk is not assessed. The calculations are carried out at a resolution of 30 " x 30 ". The main findings are an increase in population exposed of $25 \%$ by 2050, an increase in urban area exposed of $60 \%$, and an increase in 275 maximum damage of $182 \%$.

Several recent studies have expanded the DIVA approach. Schuerch et al. (2018) modified DIVA to perform a more comprehensive assessment of coastal wetland responses to climate change globally. This is done by including a wetland model that incorporates feedback between geomorphological and anthropogenic changes. They show that if enough accommodation space is left open, wetlands may gain up to $60 \%$ in area by 2100 , assuming that sediment supply stays at the present-day levels.

280 With a business as usual scenario (i.e. no further accommodation space) loss of wetland area of between 0 and $30 \%$ will occur.

\section{Early gridded study}

Fang et al (2014) assess current storm surge impacts on coastal populations and economies (GDP) by considering storm surge hazard, exposed elements and natural environmental conditions. Hazard is represented by the potential inundated area of global coastal zones, based on hourly historical water level records from the University of Hawaii Sea Level Center (UHSLC)

285 (Caldwell et al 2015). To make full use of the UHSLC dataset, information diffusion theory is applied to estimate maximum relative sea levels at tide gauges with shorter records (Huang 2012). To reflect the regional differences in hazard intensity, the inverse distance weighted interpolation method is used to extrapolate the storm surge intensity between tidal stations. Exposure is represented by population density from Oak Ridge National Laboratory (ORNL) (Bright et al 2011) and GDP from NOAA (Ghosh et al 2010), both at $1 \mathrm{~km} \mathrm{x} 1 \mathrm{~km}$ resolution. Vulnerability is not accounted for, and since the study only examines current risk, no future DRR measures are included. Results show that population risk from storm surge is spatially 
heterogeneous, with high-risk areas in the Caribbean, the Bay of Bengal, and East Asia. In terms of affected GDP, highest risk is generally found for developed countries such as the United States, China, and the United Kingdom.

Improvement in the representation of extreme sea levels

After about a decade of using the extreme water levels used in the DIVA model, Muis et al. (2016) made a significant 295 improvement in the modelling of extreme sea levels, by developing the Global Tide and Surge Reanalysis (GTSR) database. The reanalysis consists of a continuous time series of tide and surge levels based on a physically-based global coverage Global Tide and Storm surge Model (GTSM). GTSM is constructed with an unstructured mesh, so that higher resolution can be accommodated in shallow regions, whilst lower resolution is used in deep ocean. In this contribution, tides are not yet fully implemented in GTSM, and therefore the time series consists of the superposition of the tide from the Finite Element Solution

3002012 (FES2012, Carrère et al., 2012) model Muis et al. (2016) use these extreme water levels, together with a simple planar inundation model, to estimate the number of people exposed to a 100 year return period flood ( 30 ” x 30 "). Using this approach, hazard is represented in terms of inundation depth at a resolution of 30" x 30". Exposure is represented using gridded population at 30" x 30" from the GRUMPv1 population map (CIESIN, 2011). Vulnerability and DRR measures are not included in this study. The main result is that $1.3 \%$ of the world's population is exposed to a 100 year return period flood under

305 current conditions. Using the same method, Muis et al. (2017) also compare the population affected by a 100 year return period flood when using the extreme sea levels from GTSR compared to those used in original DIVA studies. They further improved the method by correcting the vertical datum between the sea-level extremes and land elevation. They show that globally the exposed population is about $28 \%$ lower when using GTSR extreme sea levels.

\section{Recent advances in global scale coastal flood risk assessment}

310 A study by Beck et al. (2018) estimates the global flood protection savings provided by coral reefs using novel methods to represent the nearshore processes. The combined effects of waves, astronomical tides, storm surge, and mean sea level are taken from numerical hindscast datasets (Losada et al., 2013), while wave propagation over the reef is modelled using $20 \mathrm{~km}$ wide coastal segments. The nearshore bathymetry is represented by integrating the shuttle radar topography mission SRTM 30" x 30" data (Farr et al., 2007) and the ETOPO bathymetry (Amanta and Eakins, 2009), and combined it with the SeaWiFS

315 (Sea-Viewing Wide Field-of-View Sensor) bathymetry for coral reefs (Stumpf et al, 1999). Changes in hazard are modelled by combining the sea level return periods with sea-level rise projections for RCP8.5 by 2100 . The population exposure is represented by population data from LandScan at 30" x 30" resolution (Bright et al., 2011). Similar to Hallegate et al., (2013), the GDP exposure is represented by built capital, which is estimated from the population identifying the ratio between built capital per capita and GDP per capita for each country. Vulnerability is represented by 1 depth-damage function taken from

320 Hinkel et al. (2014). They calculate expected annual impacts by integrating results across different exceedance probabilities. Structural flood defences are not taking into account. They conclude that across reef coastlines $(71,000 \mathrm{~km})$, reefs reduce the expected annual damage by US $\$ 4$ billion. The number of people exposed to flooding per year is reduced by more than 200,000 . Hunter et al. (2017) recently carried out a study on flood risk for the largest coastal cities following the approach of Hallegatte et al. (2013). However, they use extreme sea levels derived from tide gauges instead of those used in the original study. They 
325 find that the original extreme sea levels are overestimated compared to observations, and that average annual damages are about $30 \%$ lower using the observations.

Tiggeloven et al. (2020) apply an updated version of the GTSR dataset, including observed tropical cyclones, in order to assess risk in terms of the economic damage caused by coastal floods. Risk is assessed at a resolution of 30" x 30 ", and is calculated by integrating damages across exceedance probabilities to calculate probabilistic risk. Current protection standards per state

330 are estimated using the FLOPROS modelling approach of Scussolini et al. (2016). They simulate future risk until 2080, and also assess the costs and benefits of structural protection until the end of the $21^{\text {st }}$ century by applying a similar approach to that used by Ward et al. (2017) in their study of river flood protection. Hazard is represented by gridded inundation maps (30" $\mathrm{x}$ 30") based on extreme sea-levels from an updated version of GTSR. Current and future projections are including, using regional sea-level rise projections for the latter. The approach used is a planar inundation approach, in which attenuation is

335 accounted by using a resistance factor. Exposure is represented using the same data as Jongman et al. (2012) at 30" x 30", but for SSP1-5. Vulnerability is represented by depth-damage functions for commercial, residential, and industry, and is kept constant in the future. They us the model to explore the effectiveness of four different adaptation objectives, and find that they all show high potential to cost-effectively reduce (future) coastal flood risk at the global scale.

\section{Drought}

340 Drought is a relative concept that depends on deviations from the historical record for a specific area (Wilhite and BuchananSmith, 2005; Pereira et al., 2009; Logar and Van den Bergh, 2013). A net deficit of precipitation caused by climate variability is the starting point of all types of drought. Droughts are generally classified into four categories: meteorological, agricultural, hydrological, and socio-economic (Wilhite and Glantz, 1985). Although the concepts of drought and water scarcity are often used interchangeably, they refer to different phenomena (Pereira et al., 2009; Van Loon and Van Lanen, 2013). In this review,

345 we focus on drought risk studies.

Indicators and thresholds for drought hazard assessment at the global scale

More than 150 indices for the identification of drought and water scarcity conditions have been developed over the past decades (e.g. Wilhite and Glanz, 1985; Rijsberman, 2006; Niemeyer, 2008; Schyns et al., 2015). Indicators frequently used for the identification of hazardous drought conditions are the standardised drought indicators (e.g. Standardised Precipitation Index (SPI), Standardised Precipitation Evapotranspiration Index (SPEI), Standardised Soil Moisture Index (SSMI), Standardised Runoff Index (SRI), and Standardised Streamflow Index (SSFI)) and percentile-based drought indicators (e.g. Q80-Q90 lowflows and or precipitation conditions). More recently, assimilated drought indicators (e.g. composite drought index, multivariate standardised drought index) have been used to estimate drought hazard from a multi-sectoral perspective (Hao and AghaKouchak, 2013; Waseem et al., 2015), while fresh-water resources related approaches (e.g. the Falkenmark water

355 crowding index, or the Water Scarcity Index) have been applied to present the societal risks from fresh water shortages (during droughts) in a more holistic manner. 
Thresholds are usually applied to identify conditions of drought (Cramer and Leadbetter, 1967; Smakhtin, 2001). Thresholds can be absolute or relative, and can be either fixed throughout the year or vary over different seasons or months (e.g. Fleig et al., 2006). Thresholds for drought hazard identification (to separate between drought and no drought conditions) that are often used within drought research are ' -1 ' for standardised drought indicators and/or a ' 15 th' percentile value for the percentilebased indicators, both of them referring to a monthly value that is exceeded $\sim 85 \%$ of the time. Additional thresholds, like '1.5', '-2', or 'Q90' and 'Q95' serve as indications for moderate to severe to extreme drought conditions. These thresholds are based on pre-established baseline or reference periods, usually a period of 30 year (historical or without climate change conditions) over which the threshold values are determined, and are subsequently superimposed on time-series including climate change conditions. Some studies apply a transient threshold level, i.e. using a rolling-mean baseline reference conditions to calculate the threshold value upon estimating drought conditions under climate change (Wanders and Wada, 2015). Such approaches could be considered to implicitly take future DRR measures into account.

\section{Global drought risk assessments under current conditions}

Whilst a multitude of studies exist on the hazard of current and future droughts at the global scale, only a limited number of them combine these with information on potential exposure and/or vulnerability. To date, none of these studies assess drought risk in a probabilistic sense.

Dilley et al. (2005) is one of the first studies to conduct a global scale assessment of drought risk. In this study, risk is expressed in terms of affected people, GDP, and roads and infrastructure. The calculations are carried out at a resolution of 2.5' x 2.5'. Hazard is represented using the Weighted Anomaly of Standardized Precipitation (WASP), computed at a resolution of $2.5^{\circ} \mathrm{x}$

$3752.5^{\circ}$, whereby a drought event is identified when the magnitude of a monthly precipitation deficit is less than or equal to $50 \%$ of its long-term median value for three or more consecutive months. Exposure is represented by gridded population $\left(2.5^{\prime} \mathrm{x}\right.$ 2.5') from the Gridded Population of the World 3 (GPWv3) dataset from CIESIN and GDP per capita at national scale from World Bank, and road density data from the VMAP dataset. Vulnerability is not considered, and since the study only examines current risk, future DRR measures are not included. They find that about 38\% of the world's land area has some level of 380 drought risk, corresponding to about $70 \%$ of total population. Christenson et al. (2014) build on this assessment by extending the exposure component to make a distinction between the share of rural and urban populations exposed using GPW, GRUMP and Landscan data at resolutions from $5^{\prime} \times 5^{\prime}$ to $0.5^{\circ} \times 0.5^{\circ}$.

Yin et al. (2014) calculate drought risk in terms of maize yield at a resolution of $0.5^{\circ} \times 0.5^{\circ}$. Hazard is represented by the cumulative drought severity index, which is the normalised cumulative water stress for maize during the growing season as 385 estimated by the GEPIC-V model over the period 1971-2004 at $0.5^{\circ} \times 0.5^{\circ}$. Exposure is represented at $0.5^{\circ} \times 0.5^{\circ}$ by overlaying a 30" x 30" rainfed and irrigated field raster from USGS with maize yield data at $0.5^{\circ} \times 0.5^{\circ}$ from FAO for the period 1961 2010. Vulnerability is represented by fitted logistic regressions between historical maize loss estimates and simulations of drought stress. No future scenarios or future DRR measures are included. They find the highest maize drought risk values in South Africa, Chile, Western and Central Europe, Russia and Southeast Asia. 
390 Carrão et al. (2016) assess current drought risk using a drought index that integrates across several factors, at a resolution of $0.5^{\circ} \times 0.5^{\circ}$. Hazard is represented by the WASP, computed at $0.5^{\circ} \times 0.5^{\circ}$ grid from monthly GPCC precipitation data for 20002014. A drought event is identified when the magnitude of a monthly precipitation deficit is less than or equal to $50 \%$ of its long-term median value for three or more consecutive months. Exposure is represented by gridded agricultural areas (5' x 5') (Ramankutty et al., 2008), gridded population of the world (GPWv4, 30" x 30"), gridded livestock of the world (3' x 3')

395 (Robinson et al., 2014), and baseline water stress (WSI, catchment scale). Vulnerability is represented in the form of economic, social and infrastructural vulnerability. Proxies for these components include a large range of socioeconomic variables at a resolution of 5' x 5' to country scale, taken from various sources. Future DRR measures are not included. They highlight the importance of including a vulnerability component in drought risk assessments. In doing so, they show that drought risk is lower for remote regions, and higher for populated areas and regions extensively used for crop production and livestock

400 farming (South-Central Asia, Southeast of South America, Central Europe, and Southeast of US).

\section{Global drought risk assessments including future projections}

$\mathrm{Li}$ et al. (2009) assess the impact of climate change on risk in terms of the reduction of crop yields, by accounting for the occurrence of droughts when they happen throughout the growing season. Hazard is represented by the Palmer Drought Severity Index (PDSI) using the input of 20 climate impact models following 6 SRES scenarios towards 2050 and 2100 conditions at $0.5^{\circ} \times 0.5^{\circ}$, whereby drought is indicated by the number of months during the growing season in a year for which PDSI <-3. Exposure is represented by the normalised average yield of different crops (rice, maize, wheat, and barley) per country. Vulnerability is represented as the proportion of the area equipped for irrigation per country. Future hazard scenarios are used, but exposure and vulnerability are kept constant at current levels. They show that risk for all crops increases towards 2050 and 2100, with about a doubling until 2050 .

410 Guo et al. (2016) apply the methodologies of Li et al. (2009) and Yin et al. (2014) in an assessment of future drought risk at $0.5^{\circ} \times 0.5^{\circ}$ resolution. Risk is assessed in terms of the probability of a given loss rate of maize yield. Hazard is represented as the normalised cumulative water stress index during the growing season. This is calculated using daily ISIMIP Fast-Track data on temperature, precipitation, solar radiation, wind speed, and relative humidity at $0.5^{\circ} \times 0.5^{\circ}$ for $1971-2099$. Exposure is represented by planting area of maize (30" x 30 "), and is kept constant. Vulnerability is estimated by fitting a curve between

415 the parameters yield loss rate, normalised cumulative water stress during the growing season, and environmental indicators (elevation, slope, soil indicators, silt content, organic carbon concentration, and soil phd). They find that the expected global yield loss rate for maize is $19.2 \%$, and increases with higher return periods.

Arnell et al. (2013) examine dynamic future scenarios of drought hazard. In this study, risk is expressed in terms of exposed cropland area and change in productivity of wheat and soybean. The calculations are carried out at a resolution of $0.5^{\circ} \mathrm{x} 0.5^{\circ}$.

420 Hazard is represented by the monthly SPI $\left(0.5^{\circ} \times 0.5^{\circ}\right)$, with a 12 month accumulation period using the input of seven CMIP3 climate models. Drought conditions are identified as those periods for which the SPI is below -1, using the historical timeperiod as a baseline. Exposure is represented by global cropland area at $0.5^{\circ} \mathrm{x} 0.5^{\circ}$ (Ramankutty et al., 2008) and kept constant. Areas at risk are defined as those facing a doubling or halving in drought frequency in 2030, 2050, 2080, and 2100, and 
reported globally and for IPCC regions. Vulnerability and future DRR measures are not included. Results of this assessment show that globally the area under drought risk increases due to climate change. In a follow up study, Arnell et al. (2018) assess future risk at a resolution of $0.5^{\circ} \times 0.5^{\circ}$ using several new hazard indicators. Risk is expressed in terms of cropland area exposed to drought and affected population. Hazard is represented by the SRI and SPEI, both at $0.5^{\circ} \times 0.5^{\circ}$, using a critical threshold of -1.5 with historical conditions as a baseline and accumulation periods of 12 and 6 months respectively. For future hazard, data from $21 \mathrm{CMIP5}$ climate models are used, for scenarios of $1.5^{\circ}$ and $2^{\circ}$ warming compared to baseline. Exposure

430 of crops is represented for the current period only, using the cropland map $\left(0.5^{\circ} \times 0.5^{\circ}\right)$ of Ramankutty et al. (2008). Exposure of population is represented using a transient population scenario following SSP2 $\left(0.5^{\circ} \times 0.5^{\circ}\right)$. They find that both population affected and cropland area exposed to drought increase with rising global temperatures, with significant variation between regions.

Smirnov et al. (2016) assess drought risk due to changes in hazard and exposure (population). In this study, risk is expressed

435 in terms of affected population. The calculations are carried out at a resolution of $2^{\prime} \times 2^{\prime}$. Hazard is represented by SPEI $\left(2^{\circ} \mathrm{x}\right.$ $2^{\circ}$ ) with an accumulation period of 24 months and a threshold of -2 to express extreme drought conditions. These data are taken from 16 CMIP5 coupled climate models (Taylor et al., 2011) for RCP4.5 and RCP8.5 scenarios for 20-year time-slices towards 2100. Current exposure is represented using the Landscan 2008 high resolution global population dataset (resampled to $2^{\circ} \times 2^{\circ}$ ), and future exposure using SRES A2r projections of population growth superimposed on the current population

440 data. Vulnerability and future DRR measures are not included. They find a robust signal of increasing population exposed to drought in all climate models and scenarios, to 85.5 to 472.3 million people per year globally by 2100 . They also find that climate change is the dominant driver of increasing risk.

Liu et al. (2018) assess the impact of a $1.5^{\circ}$ and $2^{\circ}$ warming scenario on global drought risk (at a horizontal resolution of $0.5^{\circ}$ $\mathrm{x} 0.5^{\circ}$ ), using dynamic hazard and exposure scenarios. Risk is expressed in terms of the number of affected people. Hazard is

445 represented using PDSI with threshold of -3 for severe droughts, using data from 11 CMIP5 climate models (Taylor et al. 2011) $\left(0.5^{\circ} \times 0.5^{\circ}\right)$. Exposure is represented using gridded decadal population estimates (Jones and O’Neill, 2016) following the SSP1 scenario $\left(0.5^{\circ} \times 0.5^{\circ}\right)$. Vulnerability and future DRR measures are not included. They find an increase in the total population exposed to droughts globally due to climate change of +132.5 and +194.5 million under a $1.5^{\circ}$ and $2^{\circ}$ warming scenario respectively.

\section{Earthquakes}

\section{Early studies of earthquake risk hotspots}

Several global assessments used index-based methods or overlays of a single hazard map with exposure data (e.g. population, GDP) to assess global exposure to earthquake hazard (e.g. Davidson and Shah, 1997; Cardona, 2005; Hopkins, 2009; Peduzzi et al., 2009; Cardona and Carreño, 2011, Djordjević et al., 2016; Pesaresi et al., 2017). One of the first global earthquake risk models to go beyond this approach is that of Chan et al. (1998), which examines risk via macroeconomic indicators to derive 
global seismic loss. The risk indicator used is direct damage $\left(0.5^{\circ} \times 0.5^{\circ}\right)$, which is calculated for $10 \%$ exceedance probability and probable maximum intensity of the hazard. The model uses records of damaging earthquakes from 1980-1995 in order to build a loss to GDP ratio for zones where the Modified Mercalli intensity scale (MMI) is greater than or equal to six, for 29 past earthquakes. Hazard is represented at a resolution of $0.5^{\circ} \times 0.5^{\circ}$, with maps of MMI for the $10 \%$ exceedance probability

460 and the probable maximum intensity. Exposure is represented by GDP at a resolution of $0.5^{\circ} \times 0.5^{\circ}$, derived by multiplying regional GDP (World Bank, 1995) with a population map of CIESIN at a resolution of 5' x 5' (Tobler, 1995). Vulnerability is represented by a loss function that expresses an empirical relation between GDP and seismic loss, using social wealth (three classes) and a capital-GDP factor to mimic capital stock. Risk is not assessed probabilistically by integrating across different exceedance probabilities, and no future projections are undertaken.

465 Some early global earthquake risk studies identified hotspots of earthquake risk. Dilley et al. (2005) assess risk in terms of affected population, affected GDP, affected road and rail infrastructure, and fatalities under current conditions (2.5' x 2.5'). Hazard is represented at a resolution of 2.5' x 2.5' using 50 year return period data from the Global Seismic Hazard Program (GSHAP) data combined with a database of actual earthquake events greater than 4.5 on the Richter scale for 1976 to 2002 (Advanced National Seismic System, 1997). Exposure is represented by gridded population (2.5' x 2.5') from the Gridded 470 Population of the World 3 (GPWv3) dataset from CIESIN and GDP per capita at national scale from World Bank, and road density data from VMAP (developed by the National Geospatial-Intelligence Agency and made available by the USGS). Vulnerability is assessed to estimate fatalities using a ratio of affected population to reported fatalities from EM-DAT .

\section{Moving towards a fuller representation of risk}

Jaiswal and Wald (2010) assess global earthquake risk in terms of affected people and fatalities under current conditions.

475 Calculations are carried out at a resolution of $1 \mathrm{~km} \times 1 \mathrm{~km}$ and aggregated to country level. Hazard is represented by shakemaps of intensity from past events at a resolution of $1 \mathrm{~km} \times 1 \mathrm{~km}$. Exposure is represented by population from Landscan at the same resolution. Vulnerability is represented by estimating earthquake mortality rates for more than 4,500 worldwide earthquakes since 1973 and using these to develop empirical country and region-specific earthquake vulnerability models. Future DRR measures are not included, but since the fatality rates are derived from empirical data, they do inherently include seismic codes

480 and other measures for the present day. Risk is not assessed probabilistically. They find that different countries have very different fatality ratios for a certain intensity, given building typologies, quality, engineering knowledge, code implementation and how often earthquakes occur in that location. Jaiswal and Wald (2011) extend this method to also assess risk in terms of direct economic damage and affected GDP. The method is essentially the same, but exposure is represented by GDP, whereby the GDP per capita for each hazard intensity is multiplied by the total population exposed. Vulnerability is represented by 485 economic loss ratios, calibrated against losses from past earthquakes. They find a large disparity in losses across the world in terms of economic loss ratios for the same intensities.

Daniell (2014) and Daniell and Wenzel (2014) present a global approach for direct and indirect damage, fatalities, affected people, and affected GDP, at a resolution of $1 \mathrm{~km} \times 1 \mathrm{~km}$. The analysis is carried out for current conditions. Hazard is represented by the spectral acceleration and/or MMI at each point, which is then rasterised on a $1 \mathrm{~km} \mathrm{x} 1 \mathrm{~km}$ grid for each event. For 
exposure, population is represented by downscaled population for each point, rasterised to $1 \mathrm{~km} \mathrm{x} 1 \mathrm{~km}$. For capital stock, the perpetual inventory method (a method for the determination of capital stock via investment in gross fixed capital) combined with much economic data on investment is used in order to derive the capital stock at $1 \mathrm{~km} \mathrm{x} 1 \mathrm{~km}$. Subnational GDP and capital formation data are used as a proxy for investment in order to further discretise the raster. Vulnerability is represented by regression analysis based on reported events from 1900 onwards in the CATDAT database - an extensive database of over

495 10,000 damaging earthquake events (Daniell et al., 2011) - in order to derive vulnerability functions for capital stock and fatalities. Risk is not assessed probabilistically, and future scenarios or DRR measures are not included in this study. As the vulnerability functions are trended using seismic code proxies as well as the human development index over time, they could be applied for future scenarios.

Li et al. (2015) describe a global earthquake risk model for direct damage, fatalities, affected people, and affected GDP, at a 500 resolution of $0.5^{\circ} \times 0.5^{\circ}$ for mortality and $0.1^{\circ} \times 0.1^{\circ}$ for socioeconomicwealth. Risk is assessed for current conditions, and as such future DRR measures are not included. A probabilistic approach is used, in which the impacts are integrated over several exceedance probabilities. Hazard is represented by peak ground acceleration (PGA) at $0.1^{\circ} \mathrm{x} 0.1^{\circ}$ with conversion to macroseismic intensity. The economic exposure is built from investment and GDP from national estimates. Vulnerability for fatalities is represented using the fatality rates for collapse of Jaiswal and Wald (2010). Vulnerability for economic damage is represented by the work of Badal et al. (2005), using intensity based functions. They find that the usual hotspots globally explored through the hazard component show up in their risk outputs.

From the GAR2013 onwards (UNDRR, 2013, 2015a, 2017), earthquake risk in the GAR has been based on stochastic hazard modelling. Risk, in terms of direct damages, is calculated stochastically at a country resolution; and expressed at national scale in terms of Probable Maximum Loss and Annual Average Losses. Hazard is represented by spectral accelerations at a resolution of $5 \mathrm{~km} \times 5 \mathrm{~km}$, using a stochastic event set of earthquakes around the world. These are calculated using the program CRISIS 2012 and CRISIS 2015. Exposure is represented using a common dataset used throughout the GAR2015, which includes population at a horizontal resolution of $5 \mathrm{~km} \times 5 \mathrm{~km}(1 \mathrm{~km} \times 1 \mathrm{~km}$ along the coastline only) and building typologies $(5 \mathrm{~km} \times 5 \mathrm{~km})$, which are then spliced on various sectoral components such as residential, schools, hospitals and other types of capital stock (De Bono and Chatenoux, 2015). Vulnerability functions representing damages for different hazard intensities

515 are derived for each building typology using calibrated analytical functions from various case studies over an 8-year period. The combination of the modelled losses for each building class in each cell of the exposure grid is used to calculate the seismic risk for the cell. An interesting finding is that earthquakes are expected to cause high damages in places where we have not observed large losses historically.

The Global Earthquake Model (GEM) (Silva et al., 2018) has derived a probabilistic risk model using stochastic event sets to 520 produce economic loss estimates for building damage in the residential, commercial and industrial sectors ( $1 \mathrm{~km} \times 1 \mathrm{~km})$. The analysis is for current conditions, and as such future DRR measures are not included. Hazard is represented by a full stochastic event set that differs for each country around the world using a full range of spectral acceleration values, with a resolution of $1 \mathrm{~km} \times 1 \mathrm{~km}$ for each event. This is derived from a global analysis via fault and area sources and recurrence relations, including 
various regional models (SHARE, EMME, SSAHARA, SARA - Giardini et al., 2013; Şeşetyan et al., 2018). The outputs can

be derived at any resolution, however the presented resolution is a hexagonal geocell of $0.3^{\circ} \mathrm{x} 0.3^{\circ}$. Exposure is represented for building stock by using the average construction costs of the respective country (US\$/m ${ }^{2}$ ) in the residential, commercial and industrial building stock, considering the contents, structural and non-structural components. Vulnerability is represented using fragility functions for building typologies from analytical and empirical results of various authors, as detailed within the global vulnerability database (Martins and Silva, 2018). The average annual loss is calculated by combining these components.

530 The model does not consider the effects of tsunamis, liquefaction, landslides, and fires following earthquakes. The OpenQuake engine was used, which is an open-source software for seismic hazard and risk analysis developed by the GEM Foundation. For their global analysis, the event-based calculator is used. The global model has not yet been released, but those for many countries have been released.

\section{Supplementary References}

535 Advanced National Seismic System, 1997. Composite earthquake catalogue, http://quake.geo.berkeley.edu/anss. University of California, Berkeley

Alfieri, L., Bisselink, B., Dottori, F., Naumann, G., de Roo, A., Salamon, P., Wyser, K. and Feyen, L., 2017. Global projections of river flood risk in a warmer world. Earth's Future, 5, 171-182, doi:10.1002/2016EF000485

Amante, C. Eakins, B.W., 2009. ETOPO1 1 Arc-Minute Global Relief Model: Procedures, Data Sources and Analysis.

540 National Oceanic and Atmospheric Administration, Washington DC.

Arnell, N.W., Lowe, J.A., Brown, S., Gosling, S.N., Gottschalk, P., Hinkel, J., Lloyd-Hughes, B., Nicholls, R.J., Osborn, T.J., Osborne, T.M., Rose, G.A., Smith, P., Warren, R.F., 2013. A global assessment of the effects of climate policy on the impacts of climate change. Nat. Clim. Chang. 3, 512-519

Arnell, N.W., Lloyd-Hughes, B., 2014. The global-scale impacts of climate change on water resources and flooding under new

545 climate and socio-economic scenarios. Climatic Change, 122, 127-140, doi:10.1007/s10584-013-0948-4

Arnell, N.W., Gosling, S.N., 2016. The impacts of climate change on river flood risk at the global scale. Climatic Change, 134, 387-401, doi:10.1007/s10584-014-1084-5

Arnell, N.W., Lowe, J.A., Lloyd-Hughes, B., Osborn, T.J., 2018. The impacts avoided with a $1.5^{\circ} \mathrm{C}$ climate target: a global and regional assessment. Climatic Change, 147, 61-76, doi:10.1007/s10584-017-2115-9

550 Badal, J., Vazquez-Prada, M., Gonzalez, A., 2005. Preliminary quantitative assessment of earthquake casualties and damages. Natural Hazards 34, 353-374, doi:10.1007/s11069-004-3656-6.

Beck, M.W., Losada, I.J., Menéndez, P., Reguero, B.G., Díaz-Simal, P., Fernández, F., 2018. The global flood protection savings provided by coral reefs. Nature Communications, 9, 2186, doi:10.1038/s41467-018-04568-Z

Bontemps, S., Defourny, P., Bogaert, E.V., Arino, O., Kalogirou, V., Perez, J.R., 2011. GLOBCOVER 2009-Products description and validation report. Université Catholique de Louvain, Louvian 
Bright, E.A., Coleman, P.R., Rose, A.N., Urban, M.L., 2011. LandScan 2010. Oak Ridge National Laboratory, Oak Ridge TN Caldwell, P.C., Merrifield, M.A., Thompson, P.R., 2015. Sea level measured by tide gauges from global oceans - the Joint Archive for Sea Level holdings (NCEI Accession 0019568), Version 5.5, NOAA National Centers for Environmental Information

560 Cardona, O.D., 2005. Indicators of disaster risk and risk management. Summary Report, InterAmerican Development Bank, Washington DC

Cardona, O.D., Carreño, M.L., 2011. Updating the indicators of disaster risk and risk management for the Americas. IDRiM Journal, 1, 27-47.

Carrão, H., Naumann, G., Barbosa, P., 2016. Mapping global patterns of drought risk: An empirical framework based on sub565 national estimates of hazard, exposure and vulnerability. Global Environ. Chang., 39, 108-124, doi:10.1016/j.gloenvcha.2016.04.012

Carrère, L., Lyard, F., Guillot, M.C.A., Roblou, L., Cancet, M., Guillot, A., 2012. FES 2012: A new global tidal model taking advantage of nearly 20 years of altimetry. Proceedings of 20YPRA symposium, Venice, Italy, 3-8

Chan, L.S., Chen, Y., Chen, Q., Chen, L., Liu, J., Dong, W., Shah, H., 1998. Assessment of global seismic loss based on macroeconomic indicators. Nat. Hazards, 17, 269-283, doi:10.1023/A:1008060510137

Chateau, J., Rebolledo, C., Dellink, R., 2011. An economic Projection to 2050: The OECD 'ENV-Linkages' Model Baseline No. 41. OECD, Paris, doi:10.1787/5kg0ndkjufhf-en

Christenson, E., Elliott, M., Banerjee, O., Hamrick, L., Bartram, J., 2014. Climate-related hazards: a method for global assessment of urban and rural population exposure to cyclones, droughts, and floods. Int. J. Env. Res. Pub. He., 11, 2169-2192, doi:10.3390/ijerph110202169

CIESIN, 2000. Gridded Population of the World (GPW), Version 2. Center for International Earth Science Information Network (CIESIN), Columbia University; International Food Policy Research Institute (IFPRI); and World Resources Institute (WRI). CIESIN, Columbia University, Palisades, New York

CIESIN, 2005. Columbia Univ. \& CIAT. Gridded Population of the World, Version 3 (GPWv3). NASA Socioeconomic Data 580 and Applications Center (SEDAC), http://sedac.ciesin.columbia.edu/data/set/gpw-v3-population-density.

CIESIN, Columbia University International Food Policy Research Institute (IFPRI), The World Bank, and Centro Internacional de Agricultura Tropical (CIAT) (2011). Global Rural-Urban Mapping Project, Version 1 (GRUMPv1): Population Count Grid. CIESIN, Columbia University, Palisades, New York

CIESIN, 2016. Columbia University Center for International Earth Science Information Network Gridded Population of the

585 World, Version 4 (GPWv4): Population Count. CIESIN, Columbia University, Palisades, New York, doi:10.7927/H4X63JVC Cramér, H., Leadbetter, M.R., 1967. Stationary and related stochastic processes: Sample function properties and their applications. Dover Publications Inc, Mineola NY

Daniell, J.E., 2014. The development of socio-economic fragility functions for use in worldwide rapid earthquake loss estimation procedures. Doctoral Thesis, Karlsruhe 
Daniell, J.E., Khazai, B., Wenzel, F. and Vervaeck, A., 2011. The CATDAT damaging earthquakes database. Nat. Hazard. Earth Sys., 11, 2235-2251, doi:10.5194/nhess-11-2235-2011

Daniell, J.E., Wenzel, F.. 2014. The production and implementation of socioeconomic fragility functions for use in rapid worldwide earthquake loss estimation. Paper No. 490, 15th ECEE, Istanbul

Davidson, R.A., Shah, H.C., 1997. An urban earthquake disaster risk index. Stanford University, John A. Blume Earthquake

595 Engineering Center, Stanford

De Bono, A., Chatenoux B, 2015. A Global Exposure Model for GAR 2015 Background Paper prepared for the 2015 Global Assessment Report on Disaster Risk Reduction. UNDRR, Geneva

De Bruijn, J.A., De Moel, H., Jongman, B., Wagemaker, J., Aerts, J.C.J.H., 2017. TAGGS: Grouping Tweets to Improve Global Geoparsing for Disaster Response. Journal of Geovisualization and Spatial Analysis, 2, doi:10.1007/s41651-017-00106006

Dilley, M., Chen, R.S., Deichmann, U., Lerner-Lam, A., Arnold, M., Agwe, J., Buys, P., Kjekstad, O., Lyon, B., Yetman, G., 2005. Natural Disaster Hotspots. A Global Risk Analysis. The World Bank, Washington DC

Djordjević, M., Radivojević, A., Dragović, R., Filipović, I., 2016. Exposure to earthquakes - distribution and change of the world's population with regard to disposition of seismic activities. J. Geogr. Inst. Cvijic., 66, 353-370, doi: 10.2298/IJGI1603353D

Dottori, F., Salamon, P., Bianchi, A., Alfieri, L., Hirpa, F.A., Feyen, L., 2016. Development and evaluation of a framework for global flood hazard mapping, Adv. Water Resour., 94, 87-102, doi:10.1016/j.advwatres.2016.05.002

Dottori, F., Szewczyk, W., Ciscar, J. C., Zhao, F., Alfieri, L., Hirabayashi, Y., Bianchi, A., Mongelli, I., Frieler, K., Betts, R.A., Feyen, L., 2018. Increased human and economic losses from river flooding with anthropogenic warming. Nat. Clim.

610 Chang., 8, 781-786, doi:10.1038/s41558-018-0257-z

Fang, J., Sun, S., Shi, P., 2014. Assessment and mapping of potential storm surge impacts on global population and economy. Int J Disaster Risk Sci., 2014, 1-9, doi:10.1007/s13753-014-0035-0

Farr, T.G., Rosen, P.A., Caro, E., Crippen, R., Duren, R., Hensley, S., Kobrick, M., Paller, M., Rodriguez, E., Roth, L., Seal, D., Shaffer, S., Shimada, J., Umland, J., Werner, M., Oskin, M., Burbank, D., Alsdorf, D., 2007. The shuttle radar topography 615 mission. Rev. Geophys., 45, RG2004, 10.1029/2005RG000183

Fleig, A.K., Tallaksen, L.M., Hisdal, H., Demuth, S., 2006. A global evaluation of streamflow drought characteristics. Hydrol. Earth Syst. Sc. 10, 535-552, doi:10.5194/hess-10-535-2006

Fouré, J., Bénassy-Quéré, A., Fontagné, L., 2013. Modelling the world economy at the 2050 horizon. Econ. Transit., 21, 617654, doi:10.1111/ecot.12023

620 Freire, S., Kemper, T., Pesaresi, M., Florczyk, A., Syrris, V., 2015. Combining GHSL and GPW to improve global population mapping. 2015 IEEE International Geoscience \& Remote Sensing Symposium Proceedings, 2541-2543

Ghosh, T., Powell, R., Elvidge, C.D., Baugh, K.E., Sutton, P.C., Anderson, S., 2010. Shedding light on the global distribution of economic activity. The Open Geography Journal, 3, 147-160, doi:10.2174/1874923201003010147 
Giardini et al., 2013. Seismic Hazard Harmonization in Europe (SHARE). Online Data Resource, doi: 10.12686/SED

625 Gosling, S.N., Arnell, N.W., 2011. Simulating current global river runoff with a global hydrological model: model revisions, validation, and sensitivity analysis. Hydrol. Process., 25, 1129-1145, doi:10.1002/hyp.7727

Güneralp, B., Güneralp, I., Liu, Y., 2015. Changing global patterns of urban exposure to flood and drought hazards. Global Environ. Chang., 31, 217-225, doi:10.1016/j.gloenvcha.2015.01.002

Guo, H., Zhang, X., Lian, F., Gao, Y., Lin, D., Wang, J., 2016 Drought risk assessment based on vulnerability surfaces: a case 630 study of maize. Sustainability, 8, 813, doi:10.3390/su8080813

Hallegatte, S., Ranger, N., Mestre, O,. Dumas, P., Corfee-Morlot, J., Herweijer, C., Muir Wood, R., 2011. Assessing climate change impacts, sea level rise and storm surge risk in port cities: A case study on Copenhagen. Climatic Change 104, 113-137, doi:10.1007/s10584-010-9978-3

Hallegatte, S., Green, C., Nicholls, R.J., Corfee-Morlot, J., 2013. Future flood losses in major coastal cities. Nat. Clim. Change,

635 3, 802-806, doi:10.1038/nclimate1979

Hao, Z., AghaKouchak, A., 2013. Multivariate Standardized Drought Index: a parametric multi-index model. Adv. Water Resour., 57, 12-18, doi:10.1016/j.advwatres.2013.03.009

Harris, I., Jones, P.D., Osborn, T.J., Lister, D.H., 2013. Updated high-resolution grids of monthly climatic observations - the CRU TS3.10 data set. Int. J. Climatol., 34, 623-642, doi:10.1002/joc.3711

640 Hazeleger, W., Wang, X., Severijns, C., Ştefănescu, S., Bintanja, R., Ster, A., Wyser, I.K., Semmler, T., Yang, S., Van den Hurk, B., Van Noije, T., Van der Linde, E., Van der Wiel, K., 2012. EC-Earth V2.2: Description and validation of a new seamless earth system prediction model. Clim. Dynam., 39, 2611-2629, doi:10.1007/s00382-011-1228-5

Hempel, S., Frieler, K., Warszawski, L., Schewe, J., Piontek, F., 2013. A trend-preserving bias correction: the ISI-MIP approach. Earth Syst. Dynam. 4, 219-236, doi:10.5194/esd-4-219-2013

645 Hinkel, J., Klein, R.J.T., 2009. Integrating knowledge to assess coastal vulnerability to sea-level rise: The development of the DIVA tool. Global Environ. Chang., 19, 384-395, doi:10.1016/j.gloenvcha.2009.03.002

Hinkel, J., Nicholls, R.J., Vafeidis, A.T., Tol, R.S.J., Avagianou, T., 2010. Assessing risk of and adaptation to sea-level rise in the European Union: an application of DIVA. Mitig. Adapt. Strateg. Glob. Chang., 15, 703-719, doi:10.1007/s11027-0109237-y

650 Hinkel, J., Lincke, D., Vafeidis, A.T., Perrette, M., Nicholls, R.J., Tol, R.S.J., Marzeion, B., Fettweis, X., Ionescu, C., Levermann, A., 2014. Coastal flood damage and adaptation costs under 21 st century sea-level rise. P. Natl. Acad. Sci. USA., 111, 3292-3297, doi:10.1073/pnas.1222469111

Hirabayashi, Y., Kanae, S., Struthers, I., Oki, T., 2005. A 100-year (1901-2000) global retrospective estimation of terrestrial water cycle. J. Geophys. Res. Atm. 110, doi:10.2029/2004JD005492

655 Hirabayashi, Y., Kanae, S., 2009. First estimate of the future global population at risk of flooding. Hydrological Research Letters, 3, 6-9, doi:10.3178/HRL.3.6 
Hirabayashi, Y., Mahendran, R., Koirala, S., Konoshima, L., Yamazaki, D., Watanabe, S., Kim, H. and Kanae, S., 2013. Global flood risk under climate change. Nat. Clim. Chang., 3, 816-821, doi:10.1038/nclimate1911

Hoozemans, F.M.J., Marchand, M., Pennekamp, H.A., 1993. Sea Level Rise: A Global Vulnerability Assessment (GVA) -

660 vulnerability assessment for population, coastal wetlands and rice production on a global scale. Delft Hydraulics and Rijkswaterstaat, Delft and The Hague

Hopkins, D.C., 2009. Seismic Safety Indices - Tools to Motivate governments. GEM (Global Earthquake Model) Outreach Meeting, European Centre for Training and Research in Earthquake Engineering, Pavia

Huang, C.F. 2012. Risk analysis and management of natural disasters. Science Press, Beijing (in Chinese)

665 Huffman, G.J., Adler, R.F., Bolvin, D.T., Gu, G., 2009. Improving the global precipitation record: GPCP version 2.1, Geophys. Res. Lett., 36, L17808, doi:10.1029/2009GL040000

Hughes, G., Chinowsky, P., Strzepek, K., 2010. The costs of adaptation to climate change for water infrastructure in OECD countries. Util. Policy, 18, 142-153, 10.1016/j.jup.2010.03.002

Huizinga, H.J., De Moel, H., 2016. Global Flood Damage Functions - Report Tasks 1\&2: Review of Existing Data Sources

Hunter, J.R., Woodworth, P.L., Wahl, T., Nicholls, R.J., 2017. Using global tide gauge data to validate and improve the representation of extreme sea levels in flood impact studies. Global Planet. Change, 156, 34-45, doi:10.1016/j.gloplacha.2017.06.007

Jaiswal, K., Wald, D., 2010. An empirical model for global earthquake fatality estimation. Earthq. Spectra, 26, 1017-1037,

675 doi:10.1193/1.3480331

Jaiswal, K.S., Wald, D.J., 2011. Rapid estimation of the economic consequences of global earthquakes. U.S. Geological Survey Open-File Report 2011-1116. USGS, Denver

Jarvis, A., Reuter, H.I., Nelson, A., Guevara, E., 2008. Hole-filled seamless SRTM data V4. International Centre for Tropical Agriculture (CIAT), Cali

680 Jones, B., O’Neill, B.C., 2016. Spatially explicit global population scenarios consistent with the Shared Socioeconomic Pathways. Environ. Res. Lett., 11, 084003, doi:10.1088/1748-9326/11/8/084003

Jongman, B., Ward, P.J., Aerts, J.C.J.H., 2012. Global exposure to river and coastal flooding: long term trends and changes. Glob. Environ. Change 22, 823-835, doi:10.1016/j.gloenvcha.2012.07.004

Jongman, B., Winsemius, H.C., Aerts, J.C.J.H., Coughlan de Perez, E., Van Aalst, M.K., Kron, W., Ward, P.J., 2015. Declining

685 vulnerability to river floods and the global benefits of adaptation. P. Natl. Acad. Sci. USA., E2271-E2280, doi:10.1073/pnas.1414439112

Klein Goldewijk, K., Beusen, A., Van Drecht, G., De Vos, M., 2010. The HYDE 3.1 spatially explicit database of humaninduced global land-use change over the past 12000 years. Global Ecol. Biogeogr., 20, 73-86, doi:10.1111/j.14668238.2010.00587.x 
690 Kleinen, T., Petschel-Held, G., 2007. Integrated assessment of changes in flooding probabilities due to climate change. Climatic Change, 81, 283-312, doi:10.1007/s10584-006-9159-6

Klijn, F., Baan, P.J., De Bruijn, K.M., Kwadijk, J.C., Van Buren, R., 2007. Overstromingsrisico's in Nederland in een veranderend klimaat Verwachtingen, Schattingen en Berekeningen voor Het Project Nederland Later. WL/Delft Hydraulics, Delft

695 LandScan, 2008. LandScan ${ }^{\mathrm{TM}}$ Global, Oak Ridge National Laboratory, Oak Ridge, http://www.ornl.gov/sci/landscan/ Li, M., Zou, Z., Xu, G., Shi, P., 2015. Mapping earthquake risk of the world. In: Shi, P., Kasperson, R. (Eds.) World Atlas of Natural Disaster Risk. IHDP/Future Earth-Integrated Risk Governance Project Series. Springer, Berlin, Heidelberg

Li, Y., Ye, W., Wang, M., Yan, X., 2009. Climate change and drought: a risk assessment of crop-yield impacts. Clim. Res., 39, 31-46, doi:10.3354/cr00797

700 Liu, W., Sun F., Ho Lim, W., Zhang, J., Wang, H., Shiogama, H., Zhang, Y., 2018. Global drought and severe drought-affected populations in 1.5 and $2.0^{\circ} \mathrm{C}$ warmer worlds. Earth Syst. Dynamics, 9, 267-283, doi:10.5194/esd-9-267-2018

Logar, I., Van Den Bergh, J.C.J.M., 2013. Methods to assess Costs of Drought damages and policies for drought mitigation and adaptation: Review and recommendations. Water Res. M., 27, 1707-1720, doi:10.1007/s11269-012-0119-9

Losada, I.J., Reguero, B.G., Méndez, F.J.,Castanedo, S., Abascal, A.J., Mínguez, R., 2013. Long-term changes in sea-level 705 components in Latin America and the Caribbean. Global Planet. Change, 104, 34-50, doi:10.1016/j.gloplacha.2013.02.006 Lutz, W., Sanderson, W.C., Scherbov, S., 2004. The end of world population growth in the 21 st century: new challenges for human capital formation and sustainable development. Earthscan, London

Martins, L., Silva, V., 2018. A global database of vulnerability models for seismic risk assessment. 16th European Conference on Earthquake Engineering, 18-21 June 2018, Thessaloniki

710 Meehl G.A., Covey, C., Delworth, T., Latif, M., McAvaney, B., Mitchell, J.F.B., Stouffer, R.J., Taylor, K.E., 2007. The WCRP CMIP3 multi-model dataset—a new era in climate change research. B. Am. Meteorol. Soc., 88, 1383, doi:10.1175/BAMS-889-1383

Muis, S., Verlaan, M., Winsemius, H.C., Aerts, J.C.J.H., Ward, P.J., 2016. A global reanalysis of storm surges and extreme sea levels. Nat. Commun., 7, 11969. doi:10.1038/ncomms11969

715 Muis, S., Verlaan, M., Nicholls, R. J., Brown, S., Hinkel, J., Lincke, D., Vafeidis, T., Scussolini, P., Winsemius, H.C., Ward, P.J., 2017. A comparison of two global datasets of extreme sea levels and resulting flood exposure. Earth's Future, 5, 379-392, doi:10.1002/2016EF000430

Nakicenovic, N., Alcamo, J., Davis, G., De Vries, H.J.M., Fenhann, J., Gaffin, S., Gregory, K., Grubler, A., Jung, T.Y., Kram, T., La Rovere, E.L., Michaelis, L., Mori, S., Morita, T., Papper, W., Pitcher, H., Price, L., Riahi, K., Roehrl, A., Rogner, H.-

720 H., Sankovski, A., Schlesinger, M., Shukla, P., Smith, S., Swart, R., Van Rooijen, S., Victor, N., Dadi, Z., 2000. Special Report on Emissions Scenarios. IPCC, Cambridge University Press, Cambridge

Niemeyer, S., 2008. New drought indices. In López-Francos, A. (Ed.) Drought management: scientific and technological innovations. CIHEAM, Zaragoza 
Nowicki Jessee, M.A.N., Hamburger, M.W., Allstadt, K., Wald, D.J., Robeson, S.M., Tanyas, H., Hearne, M., Thompson,

E.M., 2018. A Global Empirical Model for Near-Real-Time Assessment of Seismically Induced Landslides. J. Geophys. Res.Earth, 123, 1835-1859, doi:10.1029/2017JF004494

Österle, H., Gerstengarbe, F.-W., Werner, P.-C., 2003. Homogenisierung und Aktualisierung des Klimadatensatzes der Climate Research Unit of East Anglia, Norwich. Proceedings 6th Deutsche Klimatagung, Klimavariabilität, 326-329

Peduzzi, P., Dao, H., Herold, C., Mouton, F., 2009. Assessing global exposure and vulnerability towards natural hazards: the

Disaster Risk Index. Nat. Hazard. Earth Sys., 9, 1149-1159, doi:10.5194/nhess-9-1149-2009

Pesaresi, M., Huadong, G., Blaes, X., Ehrlich, D., Ferri, S., Gueguen, L., Halkia, M., Kauffmann, M., Kemper, T., Lu, L., Marin-Herrera, M.A., Ouzounis, G.K., Scavazzon, M., Soille, P., Syrris, V., Zanchetta, L., 2013. A global human settlement layer from optical HR/VHR RS data: concept and first results, IEEE J. Sel. Top. Appl., 6, 2102-2131, doi:10.1109/JSTARS.2013.2271445

735 Pereira, L.S., Cordery, I., Iacovides, I., 2009. Coping with water scarcity: addressing the challenges. Springer Science \& Business Media, Houten

Pesaresi, M., Ehrlich, D., Kemper, T., Siragusa, A., Florczyk, A.J., Freire, S., Corban, C., 2017. Atlas of the human planet 2017: Global exposure to natural hazards. EUR 28556 EN. European Union, Brussels

Ramankutty, N., Evan, A.T., Monfreda, C., Foley, J.A., 2008. Farming the planet: 1. Geographic distribution of global 740 agricultural lands in the year 2000. Global Biogeochem. Cy., 22, Gb 1003, doi:10.1029/2007gb002952

Rijsberman, F.R., 2006. Water scarcity: Fact or fiction? Agr. Water Manage., 80, 5-22, doi:10.1016/j.agwat.2005.07.001

Robinson, T.P., Wint, G.R.W., Conchedda, G., Van Boeckel, T.P., Ercoli, V., Palamara, E., Cinardi, G., D’Aietti, L., Hay, S.I., Gilbert, M., 2014. Mapping the global distribution of livestock. PLOS ONE 9, e96084, doi:10.1371/journal.pone.0096084 Rudari, R., Silvestro, F., Campo, L., Rebora, N., Boni, G., Herold, C., 2015. Improvement of the global flood model for the 745 GAR 2015. http://www.preventionweb.net/english/hyogo/gar/2015/en/bgdocs/risksection/CIMA\%20Foundation,\%20Improvement\%20of\%20the\%20Global\%20Flood\%20Model\%20for\%20the\%20GAR15. pdf

Schuerch, M., Spencer, T., Temmerman, S., Kirwan, M. L., Wolff, C., Lincke, D., McOwen, C.J., Pickering, M.D., Reef, R., Vafeidis, A.T., Hinkel, J., Nicholls, R.J., Brown. S., 2018. Future response of global coastal wetlands to sea-level rise. Nature, 750 561, 231, doi:10.1038/s41586-018-0476-5

Schyns, J.F., Hoekstra, A.Y., Booij, M.J., 2015. Review and classification of indicators of green water availability and scarcity. Hydrol. Earth Syst. Sc., 19, 4581-4608, doi:10.5194/hess-19-4581-2015

Scussolini, P., Aerts, J.C.J.H., Jongman, B., Bouwer, L.M., Winsemius, H.C., De Moel, H., Ward, P.J., 2016. FLOPROS: An evolving global database of flood protection standards, Nat. Hazard. Earth Sys. 16, 1049-1061, doi:10.5194/nhess-16-10492016

Şeşetyan, K. et al. 2018. The 2014 Earthquake Model of the Middle East: overview and results. B. Earthq. Eng., 16, 3535, doi:10.1007/s10518-018-0346-4 
Shi, P., Kasperson, R., 2015. World Atlas of Natural Disaster Risk. IHDP/Future Earth-Integrated Risk Governance Project Series. Springer, Berlin, Heidelberg

760 Silva V., Crowley, H., Jaiswal, K., Acevedo, A.B., Pittore, M., Journey, M., 2018. Developing a global earthquake risk model. 16th European Conference on Earthquake Engineering, 18-21 June 2018, Thessaloniki

Smakhtin, V.U., 2001. Low flow hydrology: a review. J. Hydrol., 240, 147-186, doi:10.1016/S0022-1694(00)00340-1

Smirnov, O., Zhang, M., Xiao, T., Orbell, J., Lobben, A., Gordon, J., 2016. The relative importance of climate change and population growth for exposure to future extreme droughts. Climatic Change, 138, 41-53, doi:10.1007/s10584-016-1716-Z

765 Stumpf, R.H., Feldman, G.C., Kuring, N., Franz, B. Green, E., Robinson, J., 1999. SeaWiFS spies reefs. Reef Encounter, 26, 29-30.

Taylor, L.E., Stouffer, R.J., Meehl, G.A., 2012. An overview of CMIP5 and the experiment design. B. Am. Meteorol. Soc.,93, 485-498, doi:10.1175/BAMS-D-11-00094.1

Tiggeloven, T., De Moel, H., Winsemius, H.C., Eilander, D., Erkens, G., Gebremedhin, E., Diaz Loaiza, A., Kuzma., S., Luo,

770 T., Iceland, C., Bouwman, A., Van Huijstee, J., Ligtvoet, W., Ward, P.J., 2020. Global scale benefit-cost analysis of coastal flood adaptation to different flood risk drivers. Nat. Hazard. Earth Sys. Discussions, doi:10.5194/nhess-2019-330

Tobler, W., Deichmann, U., Gottsegen, J., Maloy, K., 1995. The Global Demography Project, Technical Report TR-95-6. National Center for Geographic Information and Analysis, Department of Geography, University of California, Santa Barbara United Nations, 2010. World Urbanization Prospects: The 2009 Revision, United Nations Department of Economic and Social

775 Affairs, Population Division, New York

UNDRR, 2009. Global Assessment Report 2009. Risk and Poverty in a Changing Climate. Global Assessment Report on Disaster Risk Reduction. UN Office for Disaster Risk Reduction, Geneva.

UNDRR, 2013. GAR 2013. From Shared Risk to Shared Value: the Business Case for Disaster Risk Reduction. UN Office for Disaster Risk Reduction, Geneva.

780 UNDRR (2015a) Global Assessment Report 2015. Making Development Sustainable: The Future of Disaster Risk Management. UN Office for Disaster Risk Reduction, Geneva.

UNDRR, 2015b. Sendai Framework for Disaster Risk Reduction 2015-2030 United Nations Office for Disaster Risk Reduction, Geneva, Switzerland.

UNDRR, 2017. GAR 2019. Global Assessment Report on Disaster Risk Reduction. UN Office for Disaster Risk Reduction,

785 Geneva.

Vafeidis, A.T., Nicholls, R.J., McFadden, L., Tol, R.S.J., Hinkel, J., Spencer, T., Grashoff, P.S., Boot, G., Klein, R.J.T., 2008. A new global coastal database for impact and vulnerability analysis to sea-level rise. J. Coastal Res., 24, 917-924, doi:10.2112/06-0725.1

Van Asselen, S., Verburg, P.H., 2013. Land cover change or land-use intensification: simulating land system change with a global-scale land change model. Glob. Change Biol., 19, 3648-3667, doi:10.1111/gcb.12331 
Van Beek, L.P.H., Wada, Y., Bierkens, M.F.P., 2011. Global monthly water stress: I. Water balance and water availability. Water Resour. Res., 47, W07517, doi:10.1029/2010WR009791

Van Loon, A.F., Van Lanen, H.A.J., 2013. Making the distinction between water scarcity and drought using an observationmodeling framework. Water Resour. Res., 49, 3, 1483-1502, doi:10.1002/wrcr.20147

795 Van Vuuren D.P., Den Elzen, M.G.J., Lucas, P.L., Eickhout, B., Strengers, B.J., Van Ruijven, B., Wonink, S., Van Houdt, R., 2007. Stabilizing greenhouse gas concentrations at low levels: an assessment of reduction strategies and costs. Climatic Change, 81, 119-159, doi:10.1007/s10584-006-9172-9

Van Vuuren, D. P. et al., 2017. Energy, land-use and greenhouse gas emissions trajectories under a green growth paradigm. Glob. Environ. Change 42, 237-250, doi10.1016/j.gloenvcha.2016.05.008

800 Wanders, N., Wada, Y., 2015. Human and climate impacts on the 21st century hydrological drought. J. Hydrol., 526, 208-220, doi:10.1016/j.jhydrol.2014.10.047

Ward, P.J., Jongman, B., Sperna Weiland, F., Bouwman, A., Van Beek, R., Bierkens, M.F.P., Ligtvoet, W., Winsemius, H.C., 2013. Assessing flood risk at the global scale: model setup, results, and sensitivity. Environ. Res. Lett., 8, 044019, doi:10.1088/1748-9326/8/4/044019

805 Ward, P.J., Jongman, B., Aerts, J.C.J.H., Bates, P.D., Botzen, W.J.W., Diaz Loaiza, A., Hallegatte, S., Kind, J.M., Kwadijk, J., Scussolini, P., Winsemius, H.C., 2017. A global framework for future costs and benefits of river-flood protection in urban areas. Nat. Clim. Chang., 7, 642-646, doi:10.1038/NCLIMATE3350

Waseem, M., Ajmal, M., Kim, T.-W., 2015. Development of a new composite drought index for multivariate drought assessment. J. Hydrol., 527, 30-37, doi:10.1016/j.jhydrol.2015.04.044

810 Weedon, G.P., Gomes, S., Viterbo, P., Shuttleworth, W.J., Blyth, E., Österle, H., Adam, J.C., Bellouin, N., Boucher, O., Best, M., 2011. Creation of the WATCH Forcing Data and Its Use to Assess Global and Regional Reference Crop Evaporation over Land during the Twentieth Century. J. Hydrometeorol., 12, 823-848, doi:10.1175/2011JHM1369.1

Wilhite, D.A., Buchanan-Smith, M., 2005. Drought as hazard: understanding the natural and social context. In Wilhite, D.A. (Ed.) Drought and water crises: Science, technology, and management issues. Taylor \& Francis, Boca Raton

815 Wilhite, D.A., Glantz, M.H., 1985. Understanding the Drought Phenomenon: The Role of Definitions. Water International, 10, 3, 111-120, doi:10.1080/02508068508686328

Willner, S.N., Levermann, A., Zhao, F., Frieler, K., 2018. Adaptation required to preserve future high-end river flood risk at present levels. Science Advances, 4, eaao1914, doi:10.1126/sciadv.aao1914

Winsemius, H.C., Van Beek, R., Jongman, B., Ward, P.J., Bouwman, A., 2013. A framework for global river flood risk 820 assessments. Hydrol. Earth Syst. Sc., 17, 1871-1892, doi:10.5194/hess-17-1871-2013

Winsemius, H.C., Aerts, J.C.J.H., Van Beek, L.P.H., Bierkens, M.F.P., Bouwman, A., Jongman, B., Kwadijk, J., Ligtvoet, W., Lucas, P.L., Van Vuuren, D.P., Ward, P.J., 2016. Global drivers of future river flood risk. Nat. Clim. Chang., 6, 381-385, doi:10.1038/nclimate2893

World Bank, 1995. World Development Report 1994. Infrastructure for Development, Oxford University Press, Oxford 
825 Yamazaki, D., Kanae, S., Kim, H. Oki, T., 2011. A physically based description of floodplain inundation dynamics in a global river routing model. Water Resour. Res., 47, W04501, doi:10.1029/2010WR009726

Yamin, L.E., Hurtado, A., Barbat, A.H., Cardona, O.D., 2014. Seismic and wind vulnerability assessment for the GAR-13 global risk assessment. Int. J. Disast. Risk Re., 10, 452-460, doi:10.1016/j.ijdrr.2014.05.007

Yang, W., Shen, L., Shi, P., 2015. Mapping Landslide Risk of the World. In: Shi, P., Kasperson, R. (Eds.) World Atlas of

830 Natural Disaster Risk. IHDP/Future Earth-Integrated Risk Governance Project Series. Springer, Berlin, Heidelberg

Yin, Y., Zhang, X., Lin, D., Yu, H., Wang, J., Shi, P., 2014. GEPIC-V-R model: A GIS-based tool for regional crop drought risk assessment. Agricultural Water Assessment, 144, 107-119, doi:10.1016/j.agwat.2014.05.017 